Harry F. Dahms*

\title{
Which Capital, Which Marx? Basic Income between Mainstream Economics, Critical Theory, and the Logic of Capital
}

DOI 10.1515/bis-2015-0016

\begin{abstract}
Piketty (2014) combines neoclassical economic theory and Keynesianism with an appreciation of how economic patterns and processes are tied to concrete socio-historical circumstances, and exemplifies how economists should compute in their models the socio-cultural costs accompanying economic growth and development. Piketty's concern with trends in economic inequality, returns from capital, and economic growth, addresses issues is also consistent with Marx's critique of political economy. While Piketty deems Marx's theory overly simplistic, Piketty's contention that modern democratic nation-states should confront the problem of increasing economic inequality exaggerates governments' ability to regulate the economy today. Basic income is indicative both of the diminished capacity of states to promote social welfare via established policy strategies, and the heightened need to scrutinize the specific logic of capital in the twenty-first century. Recent reinterpretations of Marx affirm the need to resist orthodox, dogmatic and non-critical readings of his analysis of the inner workings of capitalism, and are consonant with the idea of basic income.
\end{abstract}

Keywords: neoclassical economics, economic inequality, basic income, critical theory, Thomas Piketty, traditional Marxism

The fact is that we're living in a political era in which facts don't matter. This doesn't mean that those of us who care about evidence should stop seeking it out. But we should be realistic in our expectations, and not expect even the most decisive evidence to make much difference.

Paul Krugman (2015)

*Corresponding author: Harry F. Dahms, Department of Sociology, University of Tennessee, Knoxville, Tennessee, USA, E-mail: hdahms@utk.edu 


\section{Introduction}

The evidence is increasingly incontrovertible that the 1980s represent a profound sea change in the self-perception and self-understanding of modern industrialized societies. This observation applies especially as far as scholarly and political debates are concerned, to public policy, the role and functions of government, social welfare, social justice, democracy, the links between business, labor, and government, the division of labor among the social sciences, the evolutionary trajectory of capitalism, and interpretations of classical social and economic theorists, especially Karl Marx. ${ }^{1}$ In the present context, I will focus on basic income as a public policy innovation designed to combat (or, at least, to alleviate) the phenomenon of increasing economic inequality, within the coordinate system of mainstream economics, on the one hand, and renewed, explicitly non-dogmatic efforts to interpret Marx's theory as a means to illuminate the underlying logic of economically driven transformations, on the other.

Since the 1980s, proponents have promoted universal basic income as a tool of choice for remedying the persistent problem of socio-economic inequality in modern industrialized societies, along with such phenomena as structural unemployment, employment discrimination, and exclusion from the labor market (e.g., Howard, 2005; van Parijs, 1992, 1993, 1995;Widerquist, 2001, 2001a; Widerquist, Noguera, Vanderborght, \& De Wispelaere, 2013). In recent years, basic income has garnered additional attention as a possibly viable means to tackle the phenomenon of rapidly increasing economic inequality, in terms both of income and wealth. At the current historical juncture, it is not unusual for references to be made to basic income in the mainstream press (e.g., Bittman, 2015).

In this context, the research agenda Thomas Piketty has been pursuing for more than a decade, culminating for now in his widely discussed work, Capital in the Twenty-First Century (2014), produced what is to date the most ambitious, reliable and expansive dataset to provide evidence of the pattern, pace and extent of increasing inequality, especially since the 1980s. In this recent work, Piketty did not address basic income as a viable strategy to combat rising economic inequality. ${ }^{2}$ Still, as proponents of basic income have been asserting that this policy strategy may be a well-suited means for efforts to combat inequality and adjacent phenomena, the conviction of their assertion raises

1 Joseph Schumpeter and Karl Polanyi are two other prominent examples for renewed interest in foundational contributions to the theory of modern society that are economically oriented. See especially Andersen (2011), Block and Somers (2014), Dale (2010), Carayannis and Ziemnowicz (2007), and McGraw (2007), and Shionoya (1997).

2 Piketty has done so elsewhere; see the editor's introduction to this issue. 
the question: does Piketty's analysis have a bearing on the potential of basic income, if implemented effectively and in terms of stated goals, to function as a tool to reduce, if not economic inequality in general, then at least its socially, politically, culturally, educationally and medically detrimental effects on individuals and their ability to pursue life chances, and on society more generally? ${ }^{3}$

Thomas Piketty is unusual among mainstream economists working within the neoclassical paradigm, in that, while retaining elements of Keynesianism, he made it the focus of his work to critically examine the validity of one of the most cherished propositions upon which modern economics rests: that a society's increasing wealth is bound to benefit if not all, at least the vast majority of its members - and that the economic benefits outweigh whatever non-economic costs may accompany the process of attaining the former. More importantly, in adopting this stance, Piketty has positioned himself apart from the majority of economists who continue to direct their efforts at identifying and examining neglected or novel ways to seize upon existing or emerging profit opportunities, on the assumption that such efforts will translate into the further expansion of the wealth of nations. Rather than accepting such key tenets of neoclassical theory as gospel, which economists began to re-embrace and advocate on a much broader scale after the purported demise of Keynesianism as the prevailing economic policy doctrine, also during the 1980s, Piketty's work is informed by his genuine concern that economic inequality comes at a price of which to take account economists are less than well-positioned, a price that could be so high as to imperil the achievements of the modern age (see Dahms, 2015).

In order to try to provide a preliminary answer to the question of whether Piketty's analysis of patterns of rising inequality is consistent with rationales for the promotion of basic income as a public policy, I will situate his stance regarding Marx and his theory's continuing relevance in relation to current efforts by theorists in the social sciences and humanities, particularly in sociology and philosophy. Especially critical theorists in the tradition of the early Frankfurt School (see Wiggershaus, 1994) were determined to develop an up-to-date and powerful interpretation of Marx's theoretical contribution, with Postone's (1993) critique of "traditional Marxism" highlighting the problematic orientation and conclusions reached by promulgators of orthodox or traditional approaches. Tellingly, the origins of this effort to provide interpretations of Marx - focusing on his critique of political economy - with a more solid, sophisticated, and analytically compelling foundation that is geared toward illuminating twentyfirst century constellations between economy and society, conceived broadly, date back to the 1980 s as well, although it originated within the tradition of

3 See Pickett and Wilkinson (2011) and Dahrendorf (1981). 
critical theory during mid-1960s: the so-called "new Marx reading" in West Germany (see, e.g., Backhaus, 2011, esp. pp. 9-40; Bonefeld, 2014; Elbe, 2010; Reichelt, 2008). In this reading, Marx above all was concerned with the nature and logic of the modern capitalist economic process, the concurrent role of labor, and their impact in the modern age, on human sociality in general, on the relationship between humanity and nature, and on the resulting configurations of politics, culture and society - respectively, as well as across those spheres.

\section{Thomas Piketty's diagnosis of inequality in the twenty-first century}

Capital in the Twenty-First Century represents a comprehensive analysis of developments in economic inequality from the eighteenth to the twenty-first century, with an emphasis on changes in inequality alongside the historical formation of modern society. The widespread acknowledgement of, and response to, the publication of Piketty's work suggests that the results of his labor promise to and certainly should - influence attempts in coming decades to tackle inequality globally, not just in modern, capitalist and industrialized societies.

Three questions pertaining to the distribution of wealth guided Piketty's research: first, whether "the dynamics of private capital accumulation inevitably lead to the concentration of wealth in ever fewer hands, as Karl Marx believed in the nineteenth century"; secondly, whether "the balancing forces of growth, competition, and technological progress lead in later stages of development to reduced inequality and greater harmony among the classes, as Simon Kuznets thought in the twentieth century"; and thirdly, whether our knowledge regarding the evolution of wealth and income "since the eighteenth century" is reliable, and "what lessons [we] can ... derive from that knowledge for the century now underway" (Piketty, 2014, p. 1).

Piketty summarizes his main insight as follows:

When the rate of return on capital significantly exceeds the growth rate of the economy (as it did through much of history until the nineteenth century and as is likely to be the case again in the twenty-first century), then it logically follows that inherited wealth grows faster than output and income. People with inherited wealth need save only a portion of their income from capital to see that capital grows more quickly than the economy as a whole. Under such conditions, it is almost inevitable that inherited wealth will dominate wealth amassed from a lifetime's labor by a wide margin, and the concentration of capital will attain extremely high levels - levels potentially incompatible with the meritocratic values and principles of social justice fundamental to modern democratic societies (p. 26). 
Stressing that wealth accumulation and distribution contain "powerful forces pushing toward divergence, or at any rate toward an extremely high level of inequality" (p. 27), Piketty points out that his conclusions differ from what he refers to as the disheartening implications of "Marx's principle of infinite accumulation and perpetual divergence." Though Piketty does not regard divergence as perpetual, but as only one possible direction for wealth distribution in the future, he concedes that the prospects are not especially promising: with $r$ representing the rate of return on capital, and $g$ the economy's growth rate, "the fundamental $r>g$ inequality, the main force of divergence in [his] theory, has nothing to do with any market imperfection", and "the more perfect the capital market (in the economist's sense), the more likely $r$ is to be greater than g” (ibid.). Trends in income inequality, especially since the late 1970s and early 1980s, the time period during which the pattern of expanding inequality that had been in place until World War I resumed again, are consistent with a logic that Piketty contends only can be restrained politically, not economically "by Ademocratic control of capital” (pp. 569-570):

[I]t is possible to imagine public institutions and policies that would counter the effects of this implacable logic: for instance, a progressive global tax on capital. But establishing such institutions and policies would require a considerable degree of international coordination. It is unfortunately likely that actual responses to the problem - including various nationalist responses - will in practice be far more modest and less effective (p. 27).

The actual status of democratic and social justice-related values and principles in modern democratic societies are not part of Piketty's explicit consideration, to be sure, nor does he refer to the more or less paradoxical and contradictory relationship between capitalism and democracy as it has been the subject of much debate and controversy among social scientists and political philosophers. This is not surprising in that economists do not regard related issues as part of their subject domain, except in the sense of a critique of government relying to too great an extent on regulations and taxation, including democratically legitimated government. By contrast, despite mounting evidence to the contrary in many parts of the world, as we move further into the twenty-first century, Piketty appears to work from the assumption that modern societies may be viewed as both democratic and conducive to the advancement of social justice.

Piketty identifies above all four possible trajectories for regulating capital, at least in the medium term: a social-state of the twenty-first century; rethinking the progressive income tax; a global tax on capital; and a novel conception of public debt (pp. 469-570). These strategies for buffering the expansion of inequality, however, derive from and apply to the very same institutional and organizational framework that has been conducive to expanding inequality: the 
political economy of transnational capitalism in combination (if not in collusion) with more or less nominally democratic governments. If, under conditions of neoliberalism, we are to rely on democratic political systems to take responsibility for containing rising inequality and for regulating capital, with the standard tools and apparatus at their disposal, even under the most optimal circumstances, then we must doubt that the regime of political economy that was established after World War II is compatible with containing both inequality and capital. Acknowledging this condition is especially important in light of the probability that increasing inequality will amplify, at least in principle, and in various regards, an array of threats to maintaining and, especially, to further expanding, democracy. After all, especially since the 1980s, democratic political institutions and processes de facto have facilitated the expansion of economic inequality, as likely expression of more fundamental processes that occur at the social and cultural levels and as modes of adaptations to changing economic circumstances, manifesting themselves in the form of purportedly democratic processes of collective will-formation. The resulting regime of neoliberal global political economy, and the strengthening hegemony of neoliberal ideology, have been less and less conducive, even detrimental, to the values and validity of democratic principles, and to efforts to reaffirm the desirability of the latter as the necessary precondition and correlate of real solidarity between and across people (see Crouch, 2004, 2011; Dahms, 2009).

In the remainder of this essay, Piketty's (2014, p. 1) stated interest in understanding the underlying mechanisms of the distribution of wealth, and his corresponding novel framework pertaining to the relationship between the rate of return on capital and the rate of economic growth, will serve as a foil for delineating recent efforts to interpret the meaning and thrust of Marx's critique of political economy on a more convincing, sophisticated, and currently relevant foundation than well-established perspectives on the purpose and thrust of Marx's theory. I will take Piketty's repeated allusions to Marx - including the title of the book itself - as an occasion to distinguish traditional economics from social theory, as represented above all by the first generation of Frankfurt School critical theorists, especially Max Horkheimer, Herbert Marcuse and Theodor W. Adorno. Piketty's interest in the mechanisms underlying increasing economic inequality will be contrasted to the challenge of circumscribing what I will be referring to as the vanishing point of Marx's critique of political economy: delineating the "logic of capital."

While Thomas Piketty is genuinely determined to comprehend rising inequality as a symptom of processes that are not directly observable, his endeavor is hampered by limitations that are built into the design of mainstream economic theory, and modern economics in general. By contrast, critical social 
theorists working in a Marxian mold have begun to frame as one of the preeminent challenges for social scientists and social and political theorists today, the task of explaining the origins and causes of rising inequality as symptomatic of dimensions of capitalism that economists - especially those that adhere to what critical theorists have been referring to as the traditional theoretical precepts of economics - are ill-suited to confront, and which indeed may be inconceivable from the vantage point of mainstream, neoclassical economics. ${ }^{4}$

\section{Basic income: a public policy strategy for the twenty-first century}

The main difference between basic income and more standard social policy approaches is that the former is inspired by the prospect of engendering strategies that are geared towards tackling specific types of social problems which, in turn, are functions of structural inequalities. By contrast, traditional approaches to designing social policy move within a perimeter whose boundaries are determined by implicit assumptions about how existing inequalities constitute the set framework in whose context to conceive of the purpose and scope of social policies - a framework that adherents of established social policy would be hard-pressed to explicate, or even to acknowledge. Put differently, traditional approaches to public policy must be understood - and scrutinized - as a function of existing socio-economic and political contexts that are perceived as given and related to as "normal" - if not "natural." In many instances, such implicit assumptions constitute impediments to conceiving of the nature of social or economic problems on their own terms, independently of the institutional context in which, and the tools with which, they are to be alleviated, if not solved: how a given problem has come to be defined, in the context of political and economic institutions and organizations, in preceding decades. Politicians, policy makers, and even social scientists concerned with policy often do not

4 It should become apparent below that Marx's critique of political economy provides the most far-reaching basis for conceiving of the logic of capital, especially according to Postone's (1993) reinterpretation. I am not referring, though, to the logic of capitalism, which refers to the combination of a socio-historical formation and a particular ideology, despite an undeniable link between the logic of capitalism and the logic of capital. Rather, "capitalism" denotes the result of multiple yet cohesive economic processes, as they are mediated via social, political, and cultural processes that conceal the logic of capital, and which only can be scrutinized on the basis of a radical reading of the tools and categories the classics of sociology developed and provided. See Dahms (in preparation). 
have an interest in the kind of explicit, self-reflective, and critical exchanges that would be required for an understanding to result that points beyond the status quo - today, the neoliberal regime of political economy. Also frequently lacking is an interest in the specific societal context in which policy is to be constructed, whose problematic features it would have to address and endeavor to alter, what precise ends are to be pursued and achieved, and what kind of interventions are most likely to be effective. The absence of a rigorously dynamic perspective on the link between inequalities and social problems, at the cultural, organizational, and structural levels, also is a major impediment to conceptions of social policy as a means of qualitative transformation. ${ }^{5}$

Basic income-related designs diverge from implicit assumptions about the nexus between inequalities and social problems that prefigure most discussions about the purpose and scope of social policies. Most policies intended to alleviate specific social problems and conditions rest upon constructions of causality links between societal conditions, the functions and functioning of institutions, and the malleability of "human nature", on the one hand, and possibilities to alter structural inequalities by means of policy, on the other. By contrast, proponents of basic income contend that under present conditions, we are not in the position to adequately identify the link between existing inequalities and determinations of the kinds of policy designs that are possible, probable to be effective, and desirable, in a manner that would be consonant with, or translatable into, prevailing norms and values in modern democratic societies. Yet as long as assumptions about the nature of underlying causality chains remain implicit, or entirely submerged, they are prone to perpetuate and implicitly legitimate policy failures, in the sense that solutions to persistent social problems do not enter the relevant arenas, or if so, in name only. Rather, they tend to be grounded in and foster "ideology," in the sense of reference frames that negatively relate to the specific nature of problems at hand, rather than the functional character of those problems, and their structural origins in time and space, that is, in concrete socio-historical contexts. In addition, most public policies constitute efforts to justify, distract from, or rationalize, inequality in general, and specific inequalities, in particular.

Basic income reflects a genuine interest in policy designs that are oriented toward identifying necessary preconditions for solving key social problems. The latter must be seen in relation to existing structures of social and economic inequality, and economic and political power, and to past policy decisions and

5 The most compelling effort in the direction of a dynamic analysis of social problems may be Leisering and Leibfried's (1999) study of poverty in western welfare states. On problems related to the grounding of a rigorous dynamic analysis of modern western societies, see Dahms (2002). 
strategies predetermining the scope of perceived available options and future choices. At the same time, however, proponents of basic income are reluctant to adopt an explicit stance on whether, under present conditions, and especially in the most "advanced" societies, the combined political and policy apparatuses do, or do not, have the capacity to bring about qualitative change, as far as the causes of socio-economic inequalities and injustices are concerned.

How, then, do proponents reconcile the assertion that modern political systems are not capable of eliminating social problems that emanate from inequalities, with the assertion that those same systems will allow for the implementation of basic income? How would basic income facilitate - in the sense of simplify - the capacity of modern political systems to surmount the societal barriers to social policy success, to implement a new policy regime that is directed explicitly at overcoming the limitations of life chances imposed by structural inequalities? How is it that modern political systems continue to be incapable to achieve policy success (see Dahms, 2011 [2005]), but ought to be able to implement basic income? This is the central challenge to constructive arguments for basic income. While many proponents of basic income are aware of this paradox, its acknowledgement entails the risk of hampering the formulation of strategies intended to be constructive, forward-looking, optimistic.

The importance of basic income derives directly from the assertion that it is a policy design that ought to allow modern political systems, as it were, to "jump over their own shadow", i.e., to first acknowledge, and then to confront, their neglected, unsightly, disturbing, dark side. Under present conditions, solving social problems relating to inequalities does not appear to be a realistic and realizable option, yet implementing a policy innovation that increases the likelihood of future possibilities to tackle social problems more effectively, may and, indeed, must be, for an entire array of positive social, political, cultural, and technological achievements of the modern age to persist, as well as the possibility of further achievements - without the destructive correlates (preconditions, implications, consequences) overtaking the former. With the welfarestate having been, at least in part, a regime to police inequalities - without altering their nature and prevalence-and to protect against concurrent threats to social and political stability - while increasing opportunities for individuals to improve their life chances, in a manner that is compatible with the principles of liberty, equality, and solidarity: how could basic income become a reality? ${ }^{6}$ In particular, how can we make sure that basic income will not be implemented in

6 As I put it elsewhere, "In practice, the primary purpose of [social] policy has been to police social problems, not to solve them" (Dahms, 2011 [2005]: 182), manifesting itself as "a shift from policing problems to policing those who suffer from them" (ibid., p. 219n36). 
a manner that perverts the very objectives that inspire the current debate? What if the inability of modern political systems to tackle social problems is symptomatic neither of flawed policy designs, nor of a lack of commitment on the part of decision-makers in the political and policy establishments, to solve social problems by altering structures of inequality? An alternative explanation would be that there are systemic impediments in western societies - with corresponding barriers in academia and politics - which thwart attempts to implement policies that would support values relating to liberty, equality, and solidarity. Under conditions of globalization, in the context of an increasing concern with the future of the nation-state, inherent, systemic flaws and impediments to qualitative progress that took hold during the Cold War are beginning to become more visible. For present purposes, the notion of the logic of capital may provide a promising starting point for circumscribing these structural, built-in impediments and barriers.

\section{Mainstream economic theory vs. critical theory}

The problem with efforts to relate the social and economic world as represented in the tradition of neoclassical economics, to how this world appears in Marx's critique of political economy and the tradition it inspired, pertains directly to compatibility between the divergent intellectual and research orientations for which those traditions have been standing. ${ }^{7}$ While classical and neoclassical economists were working with the assumption that the variegated benefits resulting from increasing prosperity in society far outweighed the related costs, Marx along with Engels - was determined to confront the glaring absence of conceptual tools, a focused analytical mindset, and an overall theoretical framework, to assess the damage the pursuit of national wealth evidently had begun to inflict, partly via industrialization, on human beings, society, culture, politics, and nature, and to develop the requisite tools and frame to address the costs involved.

Neoclassical economics has been interested, above all, in establishing and critically examining the precepts of - the kind of knowledge on the basis of which it is possible for the spectrum of economic actors, from individuals,

7 I am referring here, as will become apparent below, to Marx's critique of political economy, specifically, as his most rigorous endeavor to provide a radical alternative to classical economic theory - which, to be sure, did not pursue the same objectives as the former - rather than his work as a whole. I will also refer to Marx's critical theory (see Postone, 1993) as an analytical, as opposed to a political, program, and the tradition whose roots are located in Marx's theoretical writings, as "Marxian", rather than "Marxist". 
via households and businesses, to entire nation-states, to enter and follow a path of increasing prosperity in a continuous, stable and reliable fashion. The discipline thus involves the establishment of microeconomic, technical knowledge about economic actors' opportunities to attain economic success, and the expansion of our understanding of macroeconomic conditions in the absence of which it would not be possible-or exceedingly difficult-to retain and build upon the fruits of previous efforts and achievement. Put differently, economists emphasize the variegated benefits that, undeniably, result from the successful pursuit of prosperity, for the various kinds of actors, and concentrates on producing the kind of knowledge that is conducive to maintaining this pursuit. Identifying and examining potential economic costs that accompany specific strategies and policies for pursuing prosperity, or for tackling economic challenges, is integral to the production of such knowledge. By implication, however, and from its outset, economics as a social science evolved in a manner that did not consider systematically the non-economic costs-which come in many different forms-that have accompanied and resulted from the expansion of economic wealth. ${ }^{8}$ In part, the neglect of noneconomic costs no doubt is due to simple lack of interest; after all, each academic discipline self-selects, is attractive to, and represented by certain personality types with particular interests, aspirations and motivations, at the exclusion of others. Over time, to be sure, the lack of interest in non-economic issues deepened and was codified, via the division of labor among the social sciences, and the concurrent emphasis of some questions, challenges, and tools, rather than others. As a consequence of this process, especially since the 1980s, the discipline of economics and its proponents and practitioners have become less able to consider the multifarious non-economic costs that inevitably accompany the pursuit of prosperity, than was true for economic theorists a century ago, when neoclassical economics began its march of victory. Admittedly, in recent decades, in the context of globalization, there has been a proliferation of research areas in economics, especially outside of the United States, whose proponents are willing to concede that economic growth comes at a price that economists ought to take into consideration.

8 This lack of interest in non-economic costs was not inevitable, though, as the founder of modern economics, the Scottish enlightenment thinker Adam Smith was keenly aware that delegating human decision-making responsibility to the self-regulating market mechanism, on the assumption that the results inevitably would be beneficial to humans, society, or humanity generally, was highly problematic and incongruous with an adequate understanding of the modern economy he advocated. See Smith ([1789] 1937), pp. 240-50, Hill and Montag (2014), and Dahms (2015). 
Still, by and large, related endeavors continue to suffer from decades of research practice characterized by narrowing horizons, general neglect of adjacent issues, professionalization, ratification of scientific standards, and the delegation of the study of purportedly non-economic challenges to other disciplines, especially sociology. ${ }^{9}$

By contrast, critical approaches to social research posit that implicit assumptions about the nature of modern societies are most in need of rigorous scrutiny. Critical theories are calibrated to examine those dimensions of modern societal life whose systematic analysis is a necessary precondition for the development of strategies for solving social problems that relate to structural inequalities. Traditional, noncritical theories-not including the classics of social theory, Marx, Durkheim and Weber, who each was more critical than dominant interpretations during the twentieth century would have conceded (see Dahms, in preparation)-either ignore these dimensions altogether, or regard and define them as aspects of the "natural" constitution of society. Lack of concern with any of these dimensions, however, makes impossible consideration of the necessary preconditions of meaningful social change that is compatible with, and advances the espoused values of, western democratic societies. In a first step, I propose the following working definition of critical theory:

Critical theories are concerned with identifying and analyzing those dimensions of social life that "traditional" theories presume as non-problematic (e.g. capitalist, gender-based, and Western definitions of social reality). The rigorously critical elucidation of these dimensions is essential to determining what it would take to solve, or to resolve once and for all, the social problems (e.g. poverty, unemployment, discrimination, exclusion) prevalent in modern societies today - in light of the fact that modern societies are not

9 No doubt it would be difficult for economists to begin to include the determination and analysis of non-economic costs in their consideration. A telling indication of how difficult it would be to overcome the hurdles involved may be found in the failure to date of economic sociology, as it has been on the rise since the 1980s, to establish a distinct agenda of its own that would be capable of immunizing itself against the appeal and gravity systematic neoclassical economic theory and analysis have been exerting on efforts to study constructively the modern economy in ways that do not position themselves explicitly against the dominant economic paradigm. Parallel to neoclassical economics attaining the status of preeminent approach within the larger field of economics, during the 1980s as the decade that has come to be associated with the rise of neoliberalism, economic sociologists started to try to produce "better" knowledge of the economy than neoclassical economists were claimed to be able to, but remained too closely tied to the tools and frameworks of the latter, transposed into sociology, and in fact incapable to escape from the draw of economics. See Sparsam (2015). On differences and tensions between economics and sociology as social sciences with competing, yet divergent claims to scientific validity and importance, see Fourcade, Ollion, and Algan (2015). 
capable of overcoming these social problems given currently prevailing conditions. The kind of fundamental change that would be necessary for solving these problems, however, would change the nature of modern society. (Dahms, 2002, p. 306).

The concept of critical theory was coined first by Max Horkheimer in 1937 (1972 [1937]). Horkheimer and his colleagues had set out from the assumption that our understanding of society is itself shaped by society, and that there is an imminent need for the kind of theory that does not reproduce the patterns of the social formation it is intended to illuminate. To achieve this feat, critical theorists first had to attain an understanding of advanced capitalism that would be conducive to future possibilities for qualitative social transformation. With regard to its research agenda, the vanishing point for such a critical theory was to be a qualitatively superior critique of political economy, to confront conditions that had taken shape by the 1930s, in light of three facts: that the relationship between state and economy had changed profoundly since the nineteenth century, that analytical and research tools had become more varied and more refined with the formation of newly established social-science disciplines, especially sociology; and that in light of both changes, perspectives on the likely and desirable future of modern societies needed to be revisited.

Along the lines of an Institute for Social Research that would rely on and integrate all the human sciences - the humanities as well as the social sciences - Horkheimer ([1931] 1993) presented an overall division of labor to be implemented and pursued at the Institute. For Marx, the critique of political economy had been an integrated endeavor, with any one element being relevant in relation to all the other elements, in order to confront the totality of modern society (see Jay, 1984), with diagnosis and critique, and theory and practice being complementary dimensions of the effort to illuminate the logic of the process of capital accumulation. By contrast, in Horkheimer's vision of the Institute for Social Research, the analysis of different dimensions of modern capitalist society was to be the responsibility of individual researchers, within an overall division of labor, while it was the charge of the entire staff to work towards the most sophisticated critique of advanced capitalism.

The members of the Institute of Social Research engaged in the critique of capitalism on three levels. On the first level, they endeavored to revitalize Marx's critique of political economy, to be applied to the stage of capitalist development reached during the first decades of the twentieth century. Acknowledging the persistent division of labor in the social sciences, Horkheimer determined that - on the second level - the members and affiliates of the Institute would be responsible for specific dimensions, e.g., for sociology, psychology, economics, or law. Since each individual social science is concerned with a specific 
analytical and theoretical agenda and set of phenomena, critical theorists started out from the assumption of the relative autonomy ("inner logic") of the social sciences' respective tasks in relation to the diverse dimensions of social life ("social value spheres") that are the domain of these disciplines (see Dahms, 1999). The goal was to critically evaluate the relative importance of different inner logics, respectively, in light of prevailing patterns determining how exactly actually existing societies fulfill an array of functions. In this context, Friedrich Pollock was responsible for providing an updated diagnosis of political economy along Marxian lines, while it fell to the community of scholars at the Institute, on the third level, to generate a highly sophisticated, systematic critique of postliberal capitalism and its effects on political, social and cultural dimensions of life. As Benhabib put it, in "Traditional and Critical Theory", Horkheimer contended

that the findings of the specialized sciences cannot be integrated with philosophy without the latter exercising a critique of the foundations upon which the sciences are based. Both the specialized sciences and those philosophical theories which consider their achievements to be the only valid model of knowledge perpetuate an epistemological illusion: the object of cognition is presented as a ready-made, ahistorical reality, and the relationship of the knowing subject to this object is presented as one of passive cognition or limited experimentation.... Traditional theories question neither the historical constitution of their own object, nor the purposes to which the knowledge they produce is put in society. (Benhabib, 1986: 152)

Since Horkheimer envisioned the core of critical theory as an explicit and systematic engagement with the gravity concrete socio-historical conditions exert on the process of social research and the development of the theory of society, including especially critical theory itself, it is necessary to establish how exactly concrete socio-historical conditions facilitate and impede the formulation of research questions, and the pursuit of research and theory. Lack of concern with regard to this issue translates more or less directly into a process of normalizing that which is specific, unusual, and especially problematic, in a manner that perpetuates and solidifies the defining features of particular societal circumstances in time and space. In modern capitalist societies, moreover, how precisely societies are modern and capitalist must be considered, recognized, and explicated fully, in order to reduce as much as possible the likelihood that the formulation of questions, and the processes of research and theory-formation themselves, reflect and are expressions of existing societal conditions. For instance, if modern capitalism is fraught with competition and the Protestant work-ethic, it follows that it is inevitable that research and theory replicate, perpetuate, and deepen competition and work-ethic, paradoxically, in the attempt to illuminate how competition and work-ethic are integral to modern society. 
Critical theory emerged as the explicit effort to track and trace the permutations of social life that resulted from the ongoing dynamics of capitalist market economies as they changed, as it were, under the feet, around the bodies, and above the heads of people living their lives, more or less successfully, in what they experienced as normalcy of everyday life. Yet, this experience was saturated by patterns endemic to corporate capitalism - without individuals being fully cognizant of this fact, and in the absence of categories and tools conducive to illuminating this condition, interpreting the latter as natural and inevitable characteristic of life in mass societies (see esp. Horkheimer and Adorno ([1944] 2002).

The distinction between traditional and critical theory is especially pertinent with respect to economic theory. The critique of political economy in the Marxian sense entails a "philosophical" dimension facilitating three types of insights: first, the core concepts of economic theory are self-contradictory (in terms of their logical implication, they are not capable of explaining the capitalist mode of production); secondly, the critique of political economy emphasizes the fact that capitalist society is not "an objective, law-governed, nature-like sphere," but "socially constituted"; and thirdly, the critique of political economy "exposes the internal contradictions and dysfunctionalities of the system in order to show how and why these give rise to oppositional demands and struggles which cannot be satisfied by the present" (Benhabib, 1986, pp. 154-55).

To put it differently, the logic of the social sciences in capitalism is itself a manifestation of the effects of capitalism: the theories of capitalism are epiphenomena of capitalism, theories in, rather than of, capitalism; they are reflections of, rather than on, capitalism. The "traditional" theories of capitalism from Smith to twentieth-century neo-classical economics are not also critiques of it - capitalism shapes the way we think to such a degree that we cannot help but reproduce its defining features and core patterns even in our theories of it.

In this context, critical theory (as arguably the most sophisticated version of Weberian Marxism) is the project of analyzing the logic of capitalist production and development, which leads from liberal capitalism to various forms of postliberal capitalism: bureaucratic capitalism, managerial capitalism, finance capitalism, and beyond - to a "totally administered world" (see Dahms, unpublished manuscript). In the process, the contingencies of an increasingly complex sociohistorical reality are reduced to means-ends relations. Critical theorists were interested in the relationship between the inner logic of capitalist production at the stage of postliberal capitalism reached during the 1920s and early 1930s, and the different inner logics of other spheres of life in society, which become increasingly assimilated to the ever more sophisticated logic of capitalist organizations, for which there is no social, cultural or political counterweight in society. Under such circumstances, the need for a systematic critical theory 
(as opposed to "traditional" neo-classical economic theory) of economic organizations as well as their relationship to the state in postliberal capitalist society became all the more urgent, since anything but a systematic critique was bound to merely reflect (in the sense of mirror), rather than reflect on, this society and its corresponding mode of capitalist production.

The agenda of the early Frankfurt School translated into the interpretation and experience of a "socially" constructed world - really, a world constructed by capital that is being experienced and interpreted as social and socially constructed - as given, as if it were possibly to presume the existence of life in modern society once and for all, whereas critical theory is a radical form of epistemology: patterns of social life exist not as persistent forms, but as expressions of the transmutations of the logic of capital. Mainstream approaches, then, need to be conceived of negatively, in terms of an absence, rather than positively, in terms of a clearly discernible characteristic: they neglect to recognize how precisely they are situated in time and space, and how they reflect concrete socio-historical configurations, on the assumption that it is possible, as it were, to step outside of modern society. In light of Horkheimer's concept of critical theory, however, doing so would be impossible (see Dahms, 2011 [2008]).

\section{Postone's reinterpretation of Marx as a critique of traditional Marxism}

Moishe Postone's Time, Labor, and Social Domination (1993) may well be the most comprehensive and sophisticated effort at a reinterpretation of Marx's social theory in the tradition of critical theory in the English language to date. His reinterpretation is also the most prominent English-language interpretation of Marx that shares themes with the "new Marx reading" mentioned earlier (dating back to West Germany in the mid-1960s). In the literal sense, such efforts as legitimating non-market work, which is one of the desired outcomes of the successful implementation of basic income, are compatible with Postone's critique of traditional Marxism, his interpretation of Marx's theory as a critical theory of labor in capitalism, and his perspective as it contributes to and supports - even though it was not meant to - the debate about basic income. The affinity between a highly refined interpretation of Marx, on the one hand, and basic income as the only serious endeavor to keep alive motives of his thought that point toward practically oriented efforts to engender change intended to be compatible with the political, social, and economic principles guiding western societies, on the other, is instructive. More specifically, the 
argument put forth by proponents of basic income, that at some point in the not necessarily so distant future the "uncoupling [of] work and income" will become a necessary precondition for continued economic growth and development, resonates well with central tenets of Postone's reinterpretation of Marx.

Modern society relies on "rationalizations" of alienated forms of life, practices, and institutional arrangements (see Dahms, 2011 [2005], esp. 167-176). Among the paradoxes of social science is that dimensions of social life that are part of the basic design of modern society, and whose consequences manifest themselves at all levels of social organization and activity, tend to remain submerged-and neglected in analyses of social life. In the absence of specifically tailored instruments, the social sciences tend to disguise these dimensions further. If strategies to implement basic income are to function as a means for overcoming the most restrictive aspects of work society, its proponents must be willing to hone in on how labor casts a net over social life, how it necessitates continuous modulations of social reality, social organization, social processes and social action, so as to facilitate the construction of meaningful life-histories, in a context fraught with irrationalities (Vidich, 1995). As Postone put it,

Marx's analysis of the historically unique character of labor as a socially mediating activity in capitalism is central to his investigation of the social relations and forms of subjectivity that characterize this society. According to Marx, the dual function of labor in capitalism as abstract labor and as concrete labor, as an activity that mediates people's relations with one another and with nature, constitutes the fundamental structuring form of social lifethe commodity (Postone, 1993, p. 385).

An adequate interpretation of Marx's theory, then, involves the challenge of understanding the nature of a specific problem-in this case, the role of "labor" in modern society-in a manner that is directly related to the nature of the problem, whether in terms of analysis, or with regard to explicitly acknowledged norms and values. Such an interpretation of Marx's theory draws attention to the degree to which, in most cases, social science is about framing the analysis of a specific problem in the context of accepted related notions. For instance, it is impossible to meet the challenge suggested by Postone's interpretation of Marx, if social scientists are not willing to question the perspective modern society has on itself as inherently progressive and evolutionary - especially insofar as such a perspective subverts possibilities to grasp the mediated nature of many, or most socially, relevant problems.

Postone's critique of traditional Marxism is a critique of most versions of Marxism, as well as a critique of "actually existing socialism.” The purpose of his critique is not to deny across the board legitimacy of previous 
interpretations and continuations of Marx's theory, but to point out a basic flaw in most interpretations of this theory during the twentieth century that can be circumscribed clearly only since the direction of the capitalist transformations underway since the 1970s has become identifiable, in terms of "globalization." He states,

By "traditional Marxism” I ...mean ...all analyses that understand capitalism-its basic social relations-essentially in terms of class relations structured by a market economy and private ownership and control of the means of production, and grasps its relations of domination primarily in terms of class domination and exploitation. Within this general interpretive framework, capitalism is characterized by a historical dynamic (driven by class conflict, capitalist competition, or technological development) which gives rise to a growing structural contradiction between the society's basic social relations (interpreted as private property and the market) and the forces of production (interpreted as the industrial mode of producing) (Postone, 1997, p. 49f).

Starting out from the observation that traditional Marxism has not been sufficiently conducive to analyzing the transformations of capitalism and their underlying dynamic, Postone endeavors to delineate the core dynamic of current transformations, and concurrent opportunities for qualitative social change (see esp. Postone, 2007). To begin with, many purported critiques of Marx's theory in fact targeted highly flawed, traditional versions of Marxism. For Postone, the key issue is how to interpret Marx's theory in order to elucidate "globalization". For our purposes, the consequences resulting from the developmental dynamic of capitalism today for the possibility of effective social policies are most crucial: how to reflect upon necessary preconditions for solving key social problems? Have arguments for basic income been impaired by key tenets of traditional Marxism? Five points are most central to Postone's critique of traditional Marxism, as a contribution to the debate about basic income.

Especially in its mature version, in Grundrisse (Marx, 1973 [1855) and Capital (Marx, 1967 [1867]) it is necessary to distinguish propositions in Marx's theory that were trans-historical and universal in nature or intent, and those that were means for analyzing liberal capitalism in the nineteenth century. We must clarify how and where Marx's theory was historically specific, and how and where it continues to be relevant in the early twenty-first century. As Marx's theory involved, but did not constitute, a theory of exploitation, a theory of surplus value, a labor theory of value, and a theory of class struggle, these "theories" were aspects of his attempt to answer the most decisive question: how to identify the nexus between bourgeois society and the capitalist mode of production, in order to distinguish between the specificity of nineteenth-century liberal capitalism and the dynamic principles of twentieth - as well as twenty-first - 
century capitalism ? $^{10}$ In his earlier writings, Marx tried to present as transhistorical certain key features of bourgeois society he later identified as specific features of nineteenth century capitalism. As in modern capitalism, the primary purpose of production is to generate profits, rather than to supply society with the means to satisfy needs, the commodity is the most fundamental form of social relations, revealing the inverted nature of business-labor-government relations in bourgeois society. At the same time, the commodity is constituted by labor whose task it is to produce commodities. In societies where profits result from the production of commodities, as the basic principle of the labor process, social relations evolve in relation to the commodity form. Yet this only applies in capitalist societies.

In addition, it is necessary to note how Marx's concept of labor was historically specific, as opposed to trans-historical, especially in his later works. The distinction between concrete labor and abstract labor draws attention to the latter fulfilling a unique social function in capitalism: to facilitate and sustain $a$ new type of social interdependence. For Marx, the category of the commodity serves the purpose to abstractly identify the underlying features of modern forms of social life - underlying features that social analysts and researchers must not neglect. In order to grasp how, in its aftermath, the thrust of Marx's theory was misconstrued by most interpreters, including especially his selfproclaimed followers, it is important to distinguish two modes of critical analysis that engender two very different interpretations: "a critique of capitalism from the standpoint of labor, ....and a critique of labor in capitalism" (Postone, 1993, p. 5). Under conditions of globalization, the commodity form is a concrete, empirically viable category for social analysis. ${ }^{11}$

Furthermore, Marx's theory was both a critique of the prevailing distribution and a critique of the prevailing mode of production in capitalism. Traditional

10 Regarding his take on twenty-first century capitalism, see Postone (forthcoming).

11 "In a society in which the commodity is the basic structuring category of the whole, labor and its products are not socially distributed by traditional ties, norms, or overt relations of power and domination-that is, by manifest social relations-as is the case in other societies. Instead, labor itself replaces those relations by serving as a kind of quasi-objective means by which the products are acquired.... [A] new form of interdependence comes into being where no one consumes what they produce, but where, nevertheless, one's own labor or labor-products function as the necessary means of obtaining the products of others.... Instead of being defined, distributed, and accorded significance by manifest social relations, as is the case in other societies, labor in capitalism is defined, distributed, and accorded significance by structures (commodity, capital) that are constituted by labor itself.... [L]abor in capitalism constitutes a form of social relations which has an impersonal, apparently non-social, quasi-objective character and which embeds, transforms, and, to some degree, undermines and supersedes traditional social ties and relations of power" (Postone, 1997, p. 59). 
Marxism concentrated on the critique of the mode of distributing wealth in capitalism, as a mechanism to reinforce the prevailing structure of social and economic inequality, neglecting the critical analysis of the organization of production, and the fact that the latter can be molded by collective actors, public authorities, governments, etc., to a degree and in a manner impossible to determine beforehand by means of either economic theory or critical theory. In capitalism, it is a definite minority that determines what is being produced, under what conditions, in whose interest, for whose benefit, with what kind of consequences for the human condition, and the future of the species. Traditional Marxists employed Marx's theory to criticize the mode of unequal distribution of the wealth produced, without acknowledging the importance of the organization of production. Yet to analyze the specific consequences resulting from the capitalist mode of production, for politics, culture, and society, and to theorize the obstacles to realizing freedom, the critique of political economy must involve a critique of the "inner logic" of the market process in capitalism, as it pertains to both distribution and production.

Thus, a new form of social domination is endemic to capitalism. What Marx had described in his early writings as "alienation" reappears, in his later work, specifically in Capital (Marx, 1967 [1867], pp. 71-83) as “commodity fetishism” referring to a "form of self-generated structural domination" (Postone, 1997, p. 62). Conceiving of this form of domination as class domination, or other forms of concrete political or economic domination, distracts from the fact that

it has no determinate locus and, although constituted by specific forms of social practice, appears not to be social at all. The structure is such that one's own needs, rather than the threat of force or of other social sanctions, appear to be the source of such "necessity."

...The Marxian analysis includes [relations of class exploitation and domination], but goes beyond it.... [T]he forms of social mediation expressed by categories such as the commodity and capital develop into a sort of objective system, which increasingly determines the goals and means of much human activity (Postone, 1997, p. 62f).

This abstract form of domination produces a peculiar kind of dynamic upon which modern society is based. This dynamic is highly complex and, which is even more important, it is not linear. Its two key characteristics are, first, that it engenders continuous transformations emanating from the economy, and affecting all aspects of life ${ }^{12}$; and secondly, that it continuously reconstitutes "its own fundamental condition as an unchanging feature of social life" where labor is

12 "[O]ngoing transformations of the technical processes of labor, of the social and detail division of labor and, more generally, of social life-of the nature, structure, and interrelations of social classes and other groupings, the nature of production, transportation, circulation, patterns of living, the form of the family, and so on" (Postone, 1997, pp. 63-64). 
the dominant mode of social mediation, and "living labor remains integral to the process of production ...regardless of the level of production” (ibid., pp. 63f).

Postone's rereading of Marx sheds light on the specific kind of impediments to understanding and theorizing modern capitalism, attempts to tackle or solve social problems, modes of collective social and political action, and opportunities to pursue qualitative social change. Implications resulting from these impediments for social policy and the prospects of basic income ought to be immediately apparent. If labor (not as the labor movement, or organized labor, etc.) is the dominant mode of mediating social relations in capitalism, then social relations are not independent from the workings of the economy, how the labor process is organized, and how workers, and citizens in general, experience their position in society. If social policy ignores the specific mediating labor in capitalism, as it permeates, influences, and even constitutes modern society in all of its dimensions, policy is bound to replicate the problematic nature of the context in which policy success is to be achieved. This applies especially with regard to existing structures of inequality, as features of modern society that are linked to the dominant mode of organizing the labor process-but not as a function of it. If proponents of basic income start out from the assumption that there is a fundamental difference between the nature of social relations in the labor process, on the one hand, and in society, on the other, and that the role of labor has not changed qualitatively, as the foundation of alienation as the foundational experience of modern social life, then proponents overlook the potential impact of basic income, and the consequences of its implementation, if successful. For instance, if the implementation of basic income is to foster the establishment of economic citizenship rights for the twenty-first century, without altering the dominant role of labor in its specificity-i.e., in terms of how it mediates social relations-the implementation of basic income will not advance the espoused objectives. After all, if we were to establish basic income, without altering the manner in which labor structures social relations, what would be its purpose?

\section{Conclusion}

Piketty's proposal of four possible trajectories for regulating capital in the medium term - a social-state of the twenty-first century; rethinking the progressive income tax; a global tax on capital; and a novel conception of public debt (2014, pp. 469-570) - at the very least to slow the increase in economic inequality, are consistent with the spirit of basic income. They also highlight the need to create circumstances that alter the conditions under which the process of 
accumulating capital occurs in the early twenty-first century. One the distinguishing features of Thomas Piketty as an unconventional mainstream economist is that he does what critical theory demands: pay attention to the specificity of socio-historical circumstances and the fact that they have a bearing on the validity and scope of well-established economic categories. Yet, per the criticisms formulated in terms of the "new Marx reading", he is not as successful at remedying the deficit in strong explanatory power of the categories economists use. For instance, that capital is much more than a quantifiable entity, and indeed an economic force that is uniquely socially transformative (see esp. Lotz, 2015), receives no attention in Capital in the Twenty-First Century. What also does not receive consideration, presumably in large part because doing so is beyond the purview of mainstream economics as a social science, is the evidence, both empirical and theoretical, that suggests that the social, economic, and political reconfigurations that began in the 1980s, are likely to have gone much deeper than the increase in inequality would suggest. The latter, instead, and perhaps in no small measure, may be indicative of the degree to which processes of individual identity-formation reflect the transformation of forms of sociality, the progressive evisceration of solidarity as a real and sustainable social force, and the assimilation of life goals and expectations to the categories and imperatives of expanding capital that corresponds with the decline of a meaningful social imaginary, and - as Habermas put it - what appears to be the final "exhaustion of utopian energies" ([1985] 1989). ${ }^{13}$ Or, as Postone (forthcoming) put it in a recent essay,

13 With a definite sense of foreboding that from today's perspective sounds like the echo of an irretrievably bygone era, Habermas (1989 [1985], pp. 64-65) wrote, "The welfare state has arrived at an impasse. With it, the energies of the utopian idea of a laboring society have exhausted themselves. The responses of the legitimists and the neoconservatives move within the medium of a Zeitgeist which at this point can only be defensive; they are the expression of a historical consciousness that has been robbed of its utopian dimension. The dissident critics of a growth-oriented society also remain on the defensive. Their response could be turned to the offensive only if the welfare state project were neither simply maintained nor simply terminated but rather continued on a higher level of reflection. A welfare state project that has become reflective, that is directed not only to restraining the capitalist economy but to controlling the state itself would, of course, lose labor as its central point of reference. For it is no longer a question of protecting full employment, which has been raised to the status of a norm. A reflective welfare state project could not even limit itself to introducing a guaranteed minimum income in order to break the spell that the labor market casts on the life history of all those capable of working - including the growing and increasingly marginalized potential of those who only stand in reserve. This step would be revolutionary, but not revolutionary enough not even if the lifeworld could be protected not only against all the inhuman imperatives of the employment system but also against the counterproductive side effects of an administrative system designed to provide for the whole existence." 
The emergence of the possibility of a future, in which surplus production no longer must be based on the labor of an oppressed class, is, at the same time, the emergence of the possibility of a disastrous development in which the growing superfluity of labor is expressed as the growing superfluity of people.

This approach, then, reconceptualizes post-capitalist society in terms of the overcoming of the proletariat and the labor it does - that is, in terms of a transformation of the general structure of labor and time. It differs both from the traditional Marxist notion of the realization of the proletariat, and from the capitalist mode of "abolishing" working classes by creating an underclass within the framework of the unequal distribution of labor and time nationally and globally. At the same time it suggests that the realization of the possibility of the abolition of proletarian labor is not only desirable, but is a necessary response to a deep structural crisis of capitalism. The possibility of historical liberation, of the liberation of humans both from and through history, emerges historically in a form such that the category of human appears as a problem for humanity.

Capital, therefore generates the possibility of a future society in a form that is increasingly destructive of the environment and the working population.

The desire for, and focus on, bringing about lasting and qualitative social and economic change by means of politics may have turned into a major impediment to related success, including on the part of social movements, as politics in the interest of meaningful change is contingent on the strong commitment among large segments of a given populace to make a profound investment of time and energy - and material resources - to demanding and pursuing political goals beyond the status quo. Rather than constituting a step toward the solution of the problem of increasing inequality, politics more and more seem like a further hurdle that must be overcome, in order to tackle rising economic inequality. Proponents of basic income, if they are committed to promoting it in theory and in practice, must begin to appreciate that the depth of the problems and challenges at hand may be much greater than the self-understanding of contemporary democratic politics - as it is entangled with, conceals, perhaps even constitutes, what used to be called "dominant ideology", i.e., in the current time-period, the increasingly single-minded approach to confronting an array of challenges on the basis of purported market principles - would allow for.

Acknowledgments: I would like to thank Lain Myers-Brown for stylistic and grammatical suggestions intended to make this essay more accessible to readers not familiar with the tradition of critical theory.

\section{References}

Andersen, E. S. (2011). Joseph A. Schumpeter. A theory of social and economic evolution. New York: Palgrave Macmillan. 
Backhaus, H. -G. (2011). Dialektik der Wertform. Untersuchungen zur marxschen Ökonomiekritik (2nd ed). Freiburg: Ça ira.

Benhabib, S. (1986). Critique, norm, and utopia. A study of the foundations of critical theory. New York: Columbia University Press.

Bittman, M. (2015). Why Not Utopia? The New York Times Sunday Review, March 20. (downloaded March 28, 2015).

Block, F. and Somers, M. (2014). The Power of Market Fundamentalism: Karl Polanyi's Critique. Cambridge, Mass.: Harvard University Press.

Bonefeld, W. (2014). Critical theory and the critique of political economy: On subversion and negative reason. New York: Bloomsbury Academic.

Carayannis, E. G. \& C. Ziemnovicz (Eds.). (2007). Rediscovering Schumpeter. Creative destruction evolving into "Mode 3". New York: Palgrave Macmillan.

Crouch, C. (2004). Post-democracy. Malden, MA: Polity.

Crouch, C. (2011). The strange non-death of neo-liberalism. Malden, MA: Polity.

Dahms, H. F. (1999). Postliberal capitalism and the early Frankfurt school: towards a critical theory of the inner logic of social value spheres. Current Perspectives in Social Theory, 19, 55-58.

Dahms, H. F. (2002). Sociology in the age of globalization: Toward a dynamic sociological theory. In J. Lehmann (Ed.), Bringing the state back in for critique by social theory (Current Perspectives of Social Theory, 21) (pp. 287-320). Amsterdam: Elsevier.

Dahms, H. F. (2009). Democracy. In G. Honor Fagan \& R. Munck (Eds.). Globalization and security, Vol. 1: Economic and political aspects (pp. 42-60). Santa Barbara, CL: Praeger Security International.

Dahms, H. F. (2011 [2005]) Globalization or hyper-alienation? Critiques of traditional Marxism as arguments for basic income. In The vitality of critical theory (Current Perspectives in Social Theory, 28) (pp. 157-222). Bingley, GB: Emerald.

Dahms, H. F. (2011 [2008]) How social science is impossible without critical theory: The immersion of mainstream approaches in time and space. In The vitality of critical theory (Current Perspectives in Social Theory, 28) (pp. 249-303). Bingley, GB: Emerald.

Dahms, H. F. (2015). Toward a critical theory of capital in the twenty-first century: Thomas Piketty between Adam Smith and the prospect of apocalypse. Critical Sociology 41(2), 359-374.

Dahms, H. F. (In preparation). Modern society as artifice: Critical theory, the dynamics of alienation, anomie, and the protestant ethics, and the logic of capital. Farnham, Surrey: Ashgate.

Dahms, H. F. (Unpublished manuscript). From Critical Theory's 'Totally Administered World' to the World of 'Finance Fascism'.

Dahrendorf, R. (1981). Life chances: Approaches to social and political theory. Chicago: University of Chicago Press.

Dale, G. (2010). Karl Polanyi: The limits of the market. Malden, MA: Polity.

Elbe, I. (2010). Marx im Westen: Die neue Marx-Lektuere in der Bundesrepublik seit 1965. Berlin: Oldenbourg Akademieverlag.

Fourcade, M., Ollion, E., \& Algan, Y. (2015). The superiority of economists. Journal of Economic Perspectives 29(1), 89-114.

Habermas, J. ([1985] 1989). The new obscurity: The crisis of the welfare state and the exhaustion of utopian energies. In The new conservatism. Cultural criticism and the historians = debate (S. W. Nicholsen, Trans.) (pp. 48-70). Cambridge, MA: MIT Press 
Hill, M., \& Montag, W. (2014). The other Adam Smith. Stanford: Stanford University Press. Horkheimer, M. ([1931] 1993). The present situation of social philosophy and the tasks of an institute of social research. In Between philosophy and social science. Selected early writings. Cambridge, MA: MIT Press.

Horkheimer, M. ([1937] 1972). Traditional and critical theory. In Critical theory. Selected essays (pp. 188-243). New York, NY: Herder and Herder.

Horkheimer, M., \& Adorno, Th. W. ([1944] 2002). Dialectic of enlightenment. Philosophical fragments (E. Jephcott, Trans.). Stanford: Stanford University Press.

Howard, M. (2005). Basic income, liberal neutrality, socialism, and work. Review of Social Economy 63(4), 613-631.

Jay, M. (1984). Marxism and totality. The adventures of a concept from Lukács to Habermas. Berkeley: University of California Press.

Krugman, P. (2015) 'Hating Good Government', The New York Times, January 18, 2015. Retrieved from http://www.nytimes.com/2015/01/19/opinion/paul-krugman-hating-good-government.html.

Leisering, L., \& Leibfried, S. (1999). Time and poverty in western welfare states. United Germany in perspective. Cambridge: Cambridge University Press.

Lotz, C. (2015). Is capital a thing? Remarks on Piketty's concept of capital. Critical Sociology 41(2), 375-383.

Marx, K. (1973 [1855]). Grundrisse. Foundations of the critique of political economy (M. Nicolaus, Trans.). New York: Random House.

Marx, K. (1967 [1867]). Capital. A critique of political economy Vol. I: The Process of Capitalist Production (S. Moore and E. Aveling, Trans.). New York: International Publishers.

McGraw, Th. K. (2007). Prophet of innovation. Joseph Schumpeter and creative destruction. Cambridge, MA: Belknap Press.

Pickett, K., \& Wilkinson, R. (2011). The spirit level: Why greater equality makes societies stronger. New York: Bloomsbury.

Piketty, T. (2014). Capital in the twenty-first century (A. Goldhammer, Trans.). Cambridge, MA: The Belknap Press of Harvard University Press.

Postone, M. (1993). Time, labor and social domination. A reinterpretation of Marx $=s$ critical theory. Cambridge: Cambridge University Press.

Postone, M. (1997). Rethinking Marx (In a post-Marxist world). In C. Camic (Ed.), Reclaiming the sociological classics: The state of the scholarship (pp. 45-80)). Malden, MA: Blackwell.

Postone, M. (2007). Theorizing the contemporary world: David Harvey, Giovanni Arrighi, Robert Brenner. In R. Albritton, B. Jessop, R. Westra (Eds.), Political economy of the present and possible global future(s). London: Anthem Press.

Postone, M. (forthcoming). The task of critical theory today: Rethinking the critique of capitalism and its futures. In H. F. Dahms (Ed.), Globalization, critique, and social theory: Diagnoses and challenges (Current Perspectives in Social Theory, 33). Bingley: Emerald, 2015.

Reichelt, H. (2008). Neue Marx-Lektüre. Zur Kritik sozialwissenschaftlicher Logik. Hamburg: VSA-Verlag.

Shionoya, Y. (1997). Schumpeter and the idea of social science. Cambridge: Cambridge University Press.

Smith, A. ([1789] 1937). An inquiry into the nature and causes of the wealth of nations. New York: The Modern Library. 
Sparsam, J. (2015). Wirtschaft in der New Economic Sociology: Eine Systematisierung und Kritik. Berlin: Springer VS.

Van Parijs, P. (Ed.). (1992). Arguing for basic income. Ethical foundations for a radical reform. London: Verso.

Van Parijs, P. (1993). Marxism recycled. Cambridge, GB: Cambridge University Press.

Van Parijs, P. (1995). Real freedom for all : What (if anything) can justify capitalism? New York: Oxford University Press.

Vidich, A. J. (1995). Toward a rational grasp of irrationality: Some gaps in social and economic theory. International Journal of Politics, Culture and Society 9(1), 5-28.

Widerquist, K. (2001). Perspectives on the guaranteed income, Part I. The Journal of Economic Issues 35(3), 749-757.

Widerquist, K. (2001a). Perspectives on the guaranteed income, Part II. The Journal of Economic Issues 35(4), 1019-1030.

Widerquist, K. Noguera, J. A., Vanderborght, Y., \& De Wispelaere, J. (Eds.). (2013). Basic income: An anthology of contemporary research. Malden, MA: Wiley-Blackwell.

Wiggershaus, R. (1994). The Frankfurt school: Its history, theories, and political significance. Cambridge, MA: MIT Press. 